\title{
The Impact of Social Media on Customers' Loyalty toward Hotels in Jordan
}

\author{
Faiz H. Zoubi ${ }^{1} \&$ Diya' Mohammad Al-Harazneh ${ }^{2}$ \\ ${ }^{1}$ The College of Business, Mutah University, Amman, Jordan \\ ${ }^{2}$ The School of Business, The University of Jordan, Amman, Jordan \\ Correspondence: Diya' Mohammad Al-Harazneh, The School of Business, The University of Jordan, Amman, \\ Jordan. E-mail: dyaharazneh@gmail.com
}

Received: March 4, 2019

doi:10.5539/ijbm.v14n5p123

\author{
Accepted: April 10, 2019 \\ Online Published: April 18, 2019 \\ URL: https://doi.org/10.5539/ijbm.v14n5p123
}

\begin{abstract}
The present study aimed at exploring the impact of social media on customers' loyalty toward the five stars hotels located in Jordan, it also aimed at exploring the impact of satisfaction as a mediating variable on the relationship between social media and customers' loyalty from the perspectives of customers and marketing managers. In more precise, to measure the mediating effect of satisfaction in the causal relationship between social media and customers' loyalty toward five stars hotels. Regression analysis and correlational coefficient were used for analysis purposive of the acquired data that were collected through a self-designed questionnaire. A sample of (200) hotel customers and (32) marketing managers was drawn from the population of the study. The major findings of the study were as follow: social media has a statistical significant effect on customer's loyalty, and on satisfaction. Satisfaction as mediating variable has a statistical significant effect on the relationship between social media and customer's loyalty. Furthermore; marketing managers were found to be having positive beliefs that social media has an effect on customers' loyalty. But communication and motivation were found to be having no significant effect on customer's loyalty.
\end{abstract}

Keywords: E-marketing, Social media benefits, customers' loyalty, hospitality, hotels in Jordan

\section{Introduction}

Social media becomes a significant part of our daily life since it has been used heavily in marketing activity in terms of advertising and transaction by various types of businesses. It is a great path for sharing information and ideas, and interacting with one another. For many companies, social media remains a great electronic avenue that can provide them with significant returns if it was used properly, It helps companies in increasing customer engagement with business activities that may be projected on attacking more customers for sales enhancement purposes.

E-marketing is used in several areas and industries, and it is usually practiced through using various electronic means. Such channels are used for delivering the intended marketing messages to the public. Therefore, much attention should be paid to internet marketing and digital channels, that's because millions of people are provided with internet accesses (Gaikwad et al., 2016). Social media is a set of applications based on internet that may build a strong and sound technical basis of Web 2.0, and that leads to building and exchanging of user created content (Kaplan and Haenlein, 2010). Social media refers to the attraction and retention of customers, and involving them through digital channels (Tabrizi et al., 2015), as well as social media has various forms, such as: weblogs, social bookmarking, micro blogging, podcasts, wikis, social blogs, pictures, rating and video (Ismail, 2017).

The customer engagement model in this regards, consists from seven stages: connection, interaction, satisfaction, retention, loyalty, advocacy, and engagement. In addition, customer engagement model was developed based on the degree of relational exchange and emotional attachment through interacting with sellers (Sashi, 2012). Social media affects many aspects of social, political, commercial and cultural life, as well as peoples' behavior and attitudes (Alalwan et al., 2016).

Numerous companies rely on e-marketing tools - like social media - in the aim of promoting a sense of loyalty among customers that increases profits, achieve competitive advantage and spread information about the brand. 
Social media is an effective tool in it's being an integrated part of strategic formation in service, trade, and manufacturing businesses. In addition to being involved in customer relationship and communication (Filo et al., 2015). In this regards, to improve companies' performance and promote brand awareness, various companies have used a variety of interactive channels to create desires and expectations among customers (Leeflang et al., 2014).

Hospitality is considered one of the most significant sectors in many countries and has a major impact on tourism. This sector is represented in hotels, cafes, motels, hotels, bars, parks etc. The success of this sector is affected by the quality of the services provided by these entities, though, these entities are more involved in activities that enhance service quality in order to attract more customers and build loyalty among customers. It should be noted that the quality customers are looking for can be identified through their attitudes and desires, where attitudes and desires can be acknowledged through communication channels, as the social media channels. Using the latter channels shall also strengthen the relationship that these entities have with their customers (Bharwani and Mathews, 2016). However, hotels sector is considered to be one of the most significant sectors that are involved with social media for marketing purposes. Thus, the present study aimed at shedding a light on the relationship between customers' use of social media and their sense of loyalty towards Jordanian hotels.

The significance of the present study lies in seeking to explore issues that researchers have investigated earlier. For example, it may be claimed that none of the researchers have studied the impact of social media on the Jordanian hotel sector. As for the present study, it is the first one that deals with such a matter.

In this context, the main objective of the present study is to investigate examine the mediating effect of customer satisfaction in the causal relationship between social media and customer's loyalty.

\subsection{Problem of the Study and Questions}

The main theme of this study is to investigate the impact of social media on customer loyalty. In relation to the current study Marzouk, (2016) has found that, social media affects customers loyalty toward product brand in which social media helps in creating loyalty and customers retention from the perspective of employees, Furthermore, social media is being considered to be a strong customer support channels to customers (Farley, 2015). As for Laroche et al. (2013), they believe that the brand communities formed through social networking websites have a strong impact on customer loyalty towards brands, and creating a brand community through social media websites can increase customers' satisfaction level. While Olsen, (2015) in his study has found no effect for visual images that were created through social networking websites on customer loyalty towards brands. However, few studies were found aimed to measure the effect of social media benefits (i.e. communication, interaction, and motivation) on customers' sense of loyalty towards the Jordanian hotels. As for the current study, its purpose is aimed at to creating a better understanding of the impact of social media on customers' behaviors and sense of loyalty towards Jordanian hotels.

The present study was conducted in the Jordanian hotel sector in which there's. A numerous numbers of hotels are marketing their services through social media and that have raised level up the competition among them. Such competition led hotels to exert effort to keep up with the latest technological developments and updates in order to enhance their performance. Therefore, the problem of the study is embedded in the title of the study to investigate the effect of social media in creating loyalty among the customers of the five stars hotel in Jordan, and to measure the effect of customer's satisfaction in this causal relationship.

\subsection{Importance of the Study}

Many businesses have ended up using marketing traditional methods and techniques, and in return have started to use e-marketing tools. Such tools include social media platforms which are considered a significant part of companies' promotional strategies.

Social media has unique characteristics in terms of its outcomes which make it different from other digital media channels, such characteristics include: achieving interactivity, collaboration across channels, integrated communication marketing across channels, and collecting information (Valos et al., 2015). Social media websites and channels have made a change in the way people search for information, communicate, and share opinions, experiences and ideas (Dieck et al., 2017).

There are many advantages and benefits for using social media networks (such as: Facebook, twitter, LinkedIn, YouTube and etc...). Such benefits include sharing information between tourists and people from different walks (Kim et al., 2016).

Social media networks provide people and customers with an access to data and information they seek in a quick easy manner. Such networks enable customers to communicate with one another and share opinions and advise 
about provided services of hotels. Such opinions vary in accordance with each customer's expectations, experiences and interests. In addition, such networks enable marketing managers in hotels industry to obtain the needed feedback and information from customers easily, and facilitates the process of communicating with customers and serve as a part of hotels' promotional campaigns.

\subsection{Objectives of the Study}

Based on the problem of the study the following may serve as the objective of the study:

1. Identifying the impact of social media benefits on customers' loyalty in Jordanian hotels.

2. Investigating the impact of communication with customers through social media in customers' loyalty in Jordanian hotels.

3. Investigating the impact of interaction through social media in Customers' loyalty in Jordanian hotels.

4. Investigating the impact of customer motivation through Social; media customers' loyalty in Jordanian hotels.

5. Identifying the mediating impact of satisfaction in the relationship between social media and customer loyalty in the Jordanian hotels

6. Identifying which benefits of social media have the greatest impact on customer loyalty in Jordanian hotels.

\section{Literature Review}

\subsection{Social Media Benefits}

Ogbuji and Papazafeiropoulou, (2016) dealt with the role of social media in developing companies. They concluded that social media can enhance companies' performance and help companies in making appropriate marketing-related decisions. They also concluded that social media can achieve a competitive advantage for the company and promote brand awareness.

In addition, Marzouk, (2016) had investigated the effectiveness of social media marketing in two significant sectors; the manufacturing and services sectors. The effects of social media on branding, sales and brand loyalty were investigated by the latter researcher. He found that brand awareness can be achieved through social media marketing tools. In addition, he indicated that increasing brand awareness shall increase the company's sales. He added too, several areas that may significantly benefit from social media marketing such are: new product launches, market share, sales, and profit margin product sales. While he found that customer loyalty toward brands is considered to be the least effected by social media marketing.

\subsection{Communication}

Teng et al. (2017) state that the electronic words of mouth (E-WOM) refers to the recommendations and advice made by customer about certain services or products. They indicate that such words of mouth - especially the ones published through social media - have a strong impact. That is because such words of mouth reach customers fast and affect the purchasing decisions made by customers.

As for Zizka, (2017), he has found that companies in hospitality industry deliver their messages to their stakeholders the through social media. Also found the two-way communication is the effective way to achieving a successful communication through social media. However, most the companies working in the hospitality sector use one-way communication. For instance, the social media websites including Facebook pages are mainly used for delivering messages and information. Many previous relevant studies have dealt with the relationship existing between company's reputation and their social responsibility. However, very few studies have dealt with the companies' social responsibility in the light of social media and the way it influences stakeholders.

\subsection{Interaction}

Aluri el al. (2015) explored the effectiveness of social media channels in improving the quality of customers' experiences in hotels. They concluded that some things were improved by social media, such things such as social interaction that occurs between customers through the websites of hotels.

Tsimonis and Dimitriadis,(2014) investigated the interaction between the company and its customers and its impact on strengthen communication with them, and found that interaction shall help in acquiring, retaining customers, enhancing customer engagement, promoting services and creating brand equity.

Riera et al., (2015) indicated in his study that social media include two aspects. The first one is the cognitive image (i.e. the perceived image) which is affected by customers' motivations, and the second aspect is the affective image 
(i.e. the emotional image) which is affected by the cognitive image.

\subsection{Motivation}

Cawsey and Rowley, (2016) conducted a study on how business to business (B2B) companies use social media strategies in developing their brands and promoting awareness about them, and they found such companies benefit from social media channels in various methods. The most common objectives behind using social media among B2B companies include: improving brand image, promoting brand awareness, and facilitating customer engagement. Based on this finding they have developed a strategy for using social media, and it is consisted from several components: monitoring and listening, empowering and engaging employees, creating compelling content, promoting a good word of mouth, evaluating channel performance, and improving brand awareness through social media.

Yuksel and Labrecque, (2016) have explored that the messages sent by the company to customers and the comments made by it shall promote empathetic reactions, modify customer's mood and emotions, inspire customers, and share interests online among the member of the brand community through using social media.

\subsection{Satisfaction}

Clark et al. (2017) proposed two main questions. What are the factors that affect customer's decisions to join a certain brand community, and how does such a decision affect his / her satisfaction about the brand? As for the second question, it is as follows: Which social media channel - (such as: Facebook, Twitter, LinkedIn, and Pinterest) - is considered to be the best suitable one for increasing the brand community size?, and such findings were drown as follows: forming a brand community can increase customer satisfaction directly, consumers who find the website personally relevant are more likely to become members of the brand community number of visits paid by customers to the company's site has a direct impact on personal relevancy and social media channels vary in relation to their extent of effectiveness.

Dieck et al. (2017) studied the relationship between customer satisfaction and customer intentions to continue buying the service from luxurious hotels in the light of using social media. A technology acceptance model was developed from the study, and found that, the use of social media channels have changed the methods of communicating, researching information, and sharing ideas, opinions and experiences. Such conclusions were achieved: continued usage intentions are mainly based on accessibility, social influence, trust, and perceived benefits.

\subsection{Customers' Loyalty}

Rehnen et al. (2017) concluded from their study that using a variety of approaches shall promote a sense of loyalty among customers. Some of those approaches include providing customers with rewards on social media. The latter study examined the way those approaches affect customer loyalty. It was concluded that adopting rewarding engagement strategies shall significantly increase customer loyalty more than adopting the rewarding transactional values solely. However, there is a concern that offering rewards may make consumers undermine the value of the product being offered. Thus, companies must protect themselves against any negative impact of rewards.

Ismail, (2017) has studied the effects of social media marketing on brand loyalty, brand awareness and value consciousness, and found that, social media marketing can significantly increase brand loyalty, and awareness and value consciousness as mediating variable were of significant effect in the relationship between social media and brand loyalty.

\section{Model of the Study}

Based on the problem of the study and literature reviewing the following model was designed with the assistants of (Marzouk, 2016; and Olsen, 2015) studies. 


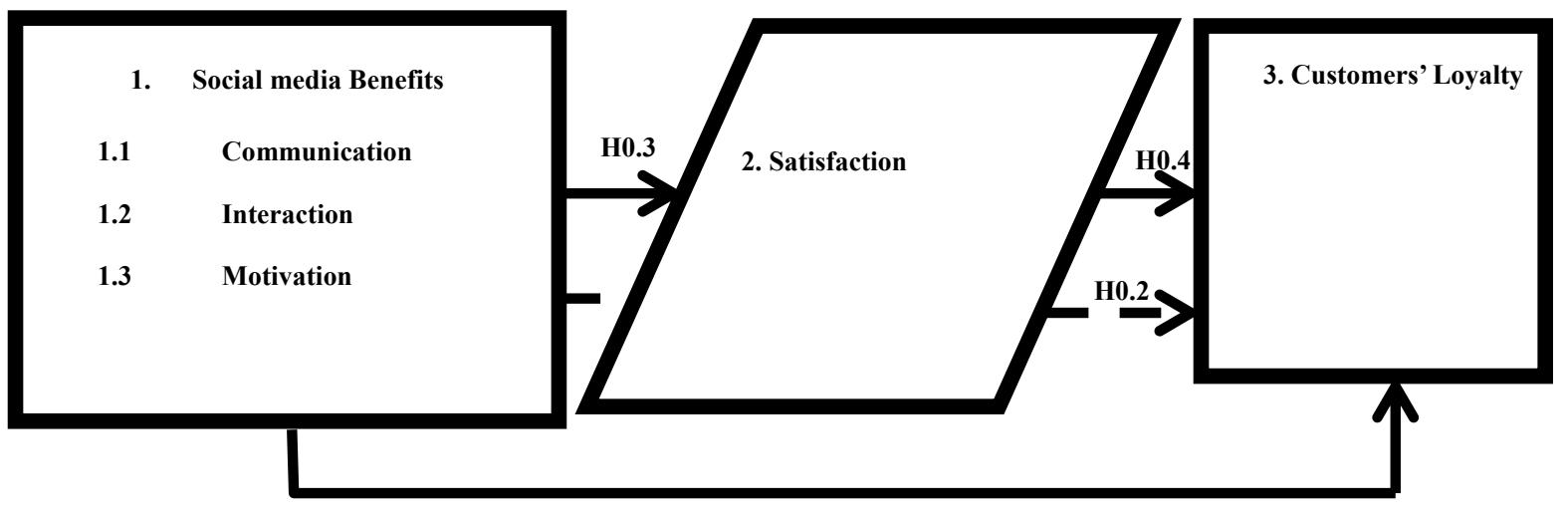

H0.1

Figure 1. Research Theoretical Framework

\subsection{Hypotheses of the Study}

Based on the model of the study and the theoretical framework the following hypotheses were formed for the purpose of the study:

HO 1: There is no statistically significant impact (at the level $\alpha \leq 0.05$ ) of social media benefits on customer loyalty in Jordanian hotels.

\subsection{Sub-Hypotheses Derived from the First Main Hypothesis}

H0 1.1: There is no statistically significant impact (at the level $\alpha \leq 0.05$ ) of communication on customer loyalty in Jordanian hotels.

H0 1.2: There is no statistically significant impact (at the level $\alpha \leq 0.05$ ) of interaction on customer loyalty in Jordanian hotels.

H0 1.3: There is no statistically significant impact (at the level $\alpha \leq 0.05$ ) of motivation on customer loyalty in Jordanian hotels.

H0 2: There isn't any mediating impact of satisfaction in the relationship between social media benefits and customer's loyalty in Jordanian hotels.

\subsection{Sub-Hypotheses Derived from the Second Main Hypothesis}

HO 2.1: There isn't any mediating impact of satisfaction in the relationship between communication and customer loyalty in Jordanian hotels.

H0 2.2: There isn't any mediating impact of satisfaction in the relationship between interaction and customer loyalty in Jordanian hotels.

HO 2.3: There isn't any mediating impact of satisfaction in the relationship between motivation and customer loyalty in Jordanian hotels.

H0 3: There is no statistically significant impact (at the level $\alpha \leq 0.05$ ) of social media benefits on satisfaction in Jordanian hotels.

\subsection{Sub-Hypotheses Derived from the Third Main Hypothesis}

H0 3.1: There is no statistically significant impact (at the level $\alpha \leq 0.05$ ) of communication on satisfaction in Jordanian hotels.

H0 3.2: There is no statistically significant impact (at the level $\alpha \leq 0.05$ ) of interaction on satisfaction in Jordanian hotels.

H0 3.3: There is no statistically significant impact (at the level $\alpha \leq 0.05$ ) of motivation on satisfaction in Jordanian hotels. 
HO 4: There is no statistically significant impact (at the level $\alpha \leq 0.05$ ) of satisfaction on customer loyalty in Jordanian hotels.

\section{Research Type and Scale}

The present study is considered a quantitative study, and has adopted the descriptive analytical approach. A self-designed questionnaire was developed by the researcher of for data collection and analysis purposes

It's formed of three parts as follows: The first part is related to the demographic data, the second part is related to the characteristics of social media, and the third part is related to body of the study which is formed of (34) questions.

The five-point Likert scale is adopted for analysis purposes ranged from strongly agree (5 points) to strongly disagree (1 point).

The study's questionnaire was designed through referring to the previous studies that are identified in the table below:

Table 1. Variables dimensions

\begin{tabular}{|c|c|c|c|}
\hline Independent & Definition & Element & References \\
\hline 1. Benefits of social media & $\begin{array}{l}\text { Social media refers to } \\
\text { processes of attracting, } \\
\text { retaining and engaging } \\
\text { customers through using } \\
\text { digital channels }\end{array}$ & $\begin{array}{l}\text { *Long term relationship. } \\
\text { *Friendly and close relationship. } \\
\text { *Helpful and informative tools. } \\
\text { *Easiness of exchanging information. } \\
\text { *Having an access to new customer } \\
\text { sales growth. }\end{array}$ & $\begin{array}{l}\text { Marzouk,(2016); } \\
\text { Das and Mandal, (2016); } \\
\text { Aluri et al. (2015); } \\
\text { Olsen, (2015); }\end{array}$ \\
\hline 1.1Communication & $\begin{array}{l}\text { It refers to the means } \\
\text { through which companies } \\
\text { seek to inform, persuade, } \\
\text { and remind consumers about } \\
\text { their brands }\end{array}$ & $\begin{array}{l}\text { *Updating information. } \\
\text { *Communication efficiency. } \\
\text { *Faster and easier. } \\
\text { *Multiple options. } \\
\text { *Feeling and thinking. } \\
\text { *Accurate information. } \\
\text { *Targeted acquisition. }\end{array}$ & $\begin{array}{l}\text { Song and Yoo (2016); } \\
\text { Zhang and Luo (2016); } \\
\text { Riera et al. (2015); } \\
\text { Tsimonis and Dimitriadis, } \\
\text { (2014); }\end{array}$ \\
\hline 1.2 Interaction & $\begin{array}{l}\text { It refers to strengthening the } \\
\text { company's with its } \\
\text { customers which is done in } \\
\text { the aim of: increasing brand } \\
\text { awareness and sales, and } \\
\text { engaging customers }\end{array}$ & $\begin{array}{l}\text { *Providing feedback. } \\
\text { *Handling customer complaints. } \\
\text { *Interacting with people from various } \\
\text { cultures and languages. } \\
\text { *Meeting customers' needs } \\
\text { *sharing information }\end{array}$ & $\begin{array}{l}\text { Marzouk, (2016); } \\
\text { Clark et al. (2017); } \\
\text { Tsimonis and Dimitriadis, } \\
\text { (2014); Yuksel and } \\
\text { Labrecque, (2016) }\end{array}$ \\
\hline 1.3 Motivation & $\begin{array}{l}\text { It refers to increasing } \\
\text { publicity, } \\
\text { competitive }\end{array}$ & $\begin{array}{l}\text { *Incentives. } \\
\text { *Competitive advantage. } \\
\text { *Customers' needs. }\end{array}$ & $\begin{array}{lr}\text { Tsimonies } & \text { and } \\
\text { Dimitriadis, } & (2014) ; \\
\text { White, (2015); } & \text { Tsimonis }\end{array}$ \\
\hline & $\begin{array}{ll}\text { cutting costs, and } \\
\text { implementing } & \text { the } \\
\text { headquarters' strategy. } & \end{array}$ & $\begin{array}{l}\text { *Customers' expectations. } \\
\text { *Customer Service Excellence. } \\
\text { *Service Quality. }\end{array}$ & $\begin{array}{l}\text { et al. (2014) ; } \\
\text { ApenesSolem, 2016; } \\
\text { Kaura, } 2015\end{array}$ \\
\hline $\begin{array}{l}\text { 2. Satisfaction (which is the } \\
\text { study's mediating variable) }\end{array}$ & $\begin{array}{l}\text { It refers to one's feelings and } \\
\text { thoughts which result from } \\
\text { conducting a comparison } \\
\text { between products in terms of } \\
\text { quality and performance } \\
\text { from the customer's own } \\
\text { perspective 's based on his / } \\
\text { her expectations }\end{array}$ & $\begin{array}{l}\text { *Motivating new customer. } \\
\text { *Integrated communication. } \\
\text { * Reinforce relationship. } \\
\text { *Follow brand page. } \\
\text { *How quick the company is in } \\
\text { delivering the service. } \\
\text { *Evaluate our performance. } \\
\text { *Sense of affiliation. }\end{array}$ & $\begin{array}{l}\text { Parveen et al. 2016; } \\
\text { Marzouk, } 2016 \text {; } \\
\text { Abu-ELSamen et } \\
\text { al .2011; Song and Yoo, } \\
\text { 2016; Aluri. 2015; Clark, } \\
\text { et al. (2017); Tsimonis } \\
\text { and Dimitriadis, (2014); }\end{array}$ \\
\hline $\begin{array}{l}\text { 3. Loyalty (which represents } \\
\text { the study's dependent } \\
\text { variable) }\end{array}$ & $\begin{array}{l}\text { It is a deep sense of } \\
\text { commitment within the } \\
\text { customer towards continuing } \\
\text { purchasing the company's } \\
\text { product or service }\end{array}$ & $\begin{array}{l}\text { * Making the brand the first choice. } \\
\text { *Increasing the information } \\
\text { possessed about the brand. } \\
\text { *Sharing opinion about the product. } \\
\text { * Making suggestions. } \\
\text { * Re-buying the product. } \\
\text { * Recommending the brand. } \\
\text { *Defending the brand. }\end{array}$ & $\begin{array}{lr}\text { Marzouk, } & 2016 ; \\
\text { ApenesSolem, } 2016 ; \\
\text { Abu-ELSamen, } \\
\text { al .2011; Kaura, 2015; } \\
\text { Song and Yoo, 2016; }\end{array}$ \\
\hline
\end{tabular}




\subsection{Data Collection Methods}

This present study adopted two types of sources to collect the required data. That was done to fulfill the study's objectives and test the study's hypotheses. The first type is represented in secondary data sources, such sources include the relevant previous studies that were reviewed by the researcher in journals, books, and periodicals. As for the primary data source, it is represented in the study's questionnaire forms which were distributed to the customers and marketing managers of the Jordanian five star hotels.

\subsection{Population and Sample of the Study}

The sampling process involves a series of operations through which several people are selected in the aim of representing the target population of the concerned study (Sekaran and Bogie, 2016). The sample of the present study was selected through using the convenience sampling method to make sure that the study's sample represents the population. Based on the relevant previous literature, Jordanian hotels rely heavily on e-marketing as being a significant part of their strategies, especially through using social media channels. The populations of the present study include the customers and marketing managers of Jordanian five star hotels who use the social media channels of those hotels.

A convenience sample was selected from the study's population. According to the Jordan Hotel Association (2016), the population includes all marketing managers working in the 32 five-star hotels. The whole population was surveyed (i.e. 32 ones). As for the sampled customers, two hundred (200) questionnaire forms were distributed to the actual customers who follow the hotel through social media.

\subsection{Data Analysis Methods}

In the present study, several statistical methods were used in order to collect, and analyzing data. That was done through using the SPSS program. Means, standard deviation, numbers and percentages, were used for descriptive analysis purposes. Multicollinearity was used for statistical relational purposes and single and multiple regressions and ANOVA were used for hypotheses testing. The (0.05) error was considered as the base decision to reject the hypotheses

\subsubsection{Validity and Reliability of the Study}

The questionnaire of the study was passed to a panel of experts consisted of marketing professors in selected number of the Jordanian universities.

In addition, the questionnaire was submitted to a pilot study sample for testing purposes consisted of 24 customers and marketing managers.

A reliability test was carried out using Cronbachs' alpha, which measures the internal consistency of a construct. The recommended minimum acceptable limit of reliability (alpha) for this measure is $(0.70)$ (George and Mallery, 2003). Table 2 reveals Cronbachs' Alpha test for each items in the questionnaire.

Table 2. Reliability analysis of the study scales

\begin{tabular}{ll}
\hline Variables & Cronbach's alpha value \\
Sample of customers & \\
\hline Social media Benefits & 0.925 \\
Communication & 0.95 \\
Interaction & 0.954 \\
Motivation & 0.943 \\
Satisfaction & 0.900 \\
Loyalty & 0.945 \\
All variables & 0.977 \\
Sample of marketing managers \\
Social media Benefits & 0.939 \\
Communication & 0.951 \\
Interaction & 0.947 \\
Motivation & 0.955 \\
Satisfaction & 0.965 \\
Loyalty & 0.93 \\
All variables & 0.989 \\
\hline
\end{tabular}


The result showed the value of alpha for the all items which indicate that all aloha values were above $(0.070)$ as shows in table 2.

\subsubsection{Normality Test}

Skewness and Kurtosis test are used to test the normality of the data. Table (3) shows that Skewness results ranged between (-1.512 to 0.646$)$ whereas Kurtosis results ranged between (--0.0149 to 2.412).

Table 3. Normality test

\begin{tabular}{|c|c|c|c|c|c|c|c|c|c|}
\hline \multicolumn{10}{|c|}{ Descriptive Statistics } \\
\hline \multirow{2}{*}{ Variables } & \multirow{2}{*}{$\begin{array}{l}\mathrm{N} \\
\text { Statistic }\end{array}$} & \multirow{2}{*}{$\begin{array}{l}\text { Minimum } \\
\text { Statistic }\end{array}$} & \multirow{2}{*}{$\begin{array}{l}\text { Maximum } \\
\text { Statistic }\end{array}$} & \multirow{2}{*}{$\begin{array}{l}\text { Mean } \\
\text { Statistic }\end{array}$} & \multirow{2}{*}{$\begin{array}{l}\text { Std. } \\
\text { Deviation } \\
\text { Statistic }\end{array}$} & \multicolumn{2}{|l|}{ Skewness } & \multicolumn{2}{|l|}{ Kurtosis } \\
\hline & & & & & & Statistic & $\begin{array}{l}\text { Std. } \\
\text { Error }\end{array}$ & Statistic & Std. Error \\
\hline benefits & 200 & 1.00 & 5.00 & 3.9638 & .83816 & -1.390 & .172 & 2.412 & .342 \\
\hline communication & 200 & 1.00 & 5.00 & 3.9136 & .85641 & -1.481 & .172 & 2.329 & .342 \\
\hline interaction & 200 & 1.00 & 5.00 & 3.7850 & .88422 & -1.358 & .172 & 1.702 & .342 \\
\hline motivation & 200 & 1.00 & 5.00 & 4.0780 & .91548 & -1.512 & .172 & 2.201 & .342 \\
\hline satisfaction & 200 & 1.00 & 5.00 & 3.6200 & .83177 & -1.146 & .172 & 1.706 & .342 \\
\hline loyalty & 200 & 1.00 & 5.00 & 2.6050 & 1.01087 & .646 & .172 & -.049 & .342 \\
\hline Valid N (listwise) & 200 & & & & & & & & \\
\hline
\end{tabular}

\subsubsection{Collinearity Statistics Test}

Multi-collinearity between the independent variables is checked using the Collinearity statistics: Tolerance and Variance Inflation Factor (VIF). The minimum acceptable cutoff value for tolerance is typically $(0.10)$. The maximum acceptable cutoff value for the VIF is (10).

Table 4. Collinearity Statistics Test

\begin{tabular}{lll}
\hline Model & $\begin{array}{l}\text { Collinearity Statistics } \\
\text { Tolerance }\end{array}$ & VIF \\
\hline communication & 0.172 & 5.816 \\
interaction & 0.149 & 6.710 \\
motivation & 0.183 & 5.476 \\
\hline
\end{tabular}

The above table shows that VIF values for each independent variable is less than 10, with tolerance (0.149-0.183). This means that there is no occurrence for any multicollinearity problem between the independent variables.

\subsection{Test of Hypotheses}

\subsubsection{The First Main Hypothesis}

This section presents the statistical testing of the hypotheses of the study:

Table 5. Model summary

\begin{tabular}{llllll}
\hline Model & $\mathrm{R}$ & R Square & Adjusted R Square & $\begin{array}{l}\text { Std. Error of the } \\
\text { Estimate }\end{array}$ \\
\hline 1 & $.414 \mathrm{a}$ & .172 & .159 & .92713 & \\
\hline
\end{tabular}

a. Predictors: (Constant), motivation, communication, interaction.

Multiple Regressions is used to test the above hypothesis. Table (5) shows that $\mathrm{R}(0.414)$ is the impact of the independent variables on customer loyalty. Also it is found that R Square (0.172), which is the explained variance, is actually the square of the multiple $\mathrm{R}(0.414) 2$. What the results mean is that $(17.2 \%)$ of the variance (R-Square) in the customer loyalty variable was significantly explained by the independent variables. 
Table 6. ANOVAa

\begin{tabular}{lllllll}
\hline & & \multicolumn{3}{c}{ Sum of Squares } & Mean Square & F \\
Model & & & df & & Sig. \\
\hline \multirow{3}{*}{1} & Regression & 34.875 & 3 & 11.625 & 13.524 & $.000 \mathrm{~b}$ \\
& Residual & 168.476 & 196 & .860 & & \\
& Total & 203.351 & 199 & & & \\
\hline
\end{tabular}

The ANOVA table shows that the F value of (13.524) is significant at (0.05) level. Thus, there is statistically significant impact of social media benefits on customer loyalty.

Table 7. Coefficientsa

\begin{tabular}{|c|c|c|c|c|c|c|}
\hline \multirow{2}{*}{ Model } & & \multicolumn{2}{|c|}{ Unstandardized Coefficients } & \multicolumn{3}{|l|}{ Standardized } \\
\hline & & $\mathrm{B}$ & Std. Error & Beta & & \\
\hline \multirow{4}{*}{1} & (Constant) & .787 & .314 & & 2.508 & .013 \\
\hline & communication & .081 & .185 & .068 & .435 & .664 \\
\hline & interaction & .435 & .193 & .380 & 2.259 & .025 \\
\hline & motivation & -.035 & .168 & -.032 & -.210 & .834 \\
\hline
\end{tabular}

a. Dependent Variable: loyalty.

Also according to the coefficient table it is found that $\mathrm{T}_{-}$value for the variable (interaction) is significant at $\mathrm{P}$ (0.05) levels. From the tables we conclude that:

- $\quad$ There is a statistical significant impact of social media benefits collectively on customer loyalty.

- There is no statistically significant impact of communication on customer loyalty since P was above (0.05).

- There is a statistical significant impact of interaction on customer loyalty.

- $\quad$ There is no statistically significant impact of motivation on customer loyalty since P was above (0.05).

4.4.2 The Second Main Hypothesis

- $\quad$ To test the hypothesis, a structural equation model (SEM) was used. The software IBM SPSS Amos 23 was used. It is found that $x 2=0.532$ is not significant at 0.05 level that means the model is fit. (RMSEA, PCLOSE) were used to evaluate the model-data fit. The structural model had CMIN=0.532, GFI $=0.998, \mathrm{RMSEA}=0.000$.

Table 8. The Model Well Satisfied the Requirements of Goodness-of-Fit Criteria

\begin{tabular}{|c|c|c|c|c|c|c|}
\hline & Chi-squar & & & 0.532 & & \\
\hline & Degrees o & freedom & & 1 & & \\
\hline & Probabilit & level & & 0.466 & & \\
\hline & CMIN & & & 0.532 & & \\
\hline & GFI & & & 0.998 & & \\
\hline & RMSEA & & & 000 & & \\
\hline & AGFI & & & 0.989 & & \\
\hline & CFI & & & 1 & & \\
\hline & & Estimate & S.E. & C.R. & $\mathrm{P}$ & Label \\
\hline satisfaction & $<---$ benefits & .830 & .039 & 21.500 & $* * *$ & \\
\hline loyalty & $<---$ satisfacti & n.673 & .072 & 9.376 & $* * *$ & \\
\hline
\end{tabular}




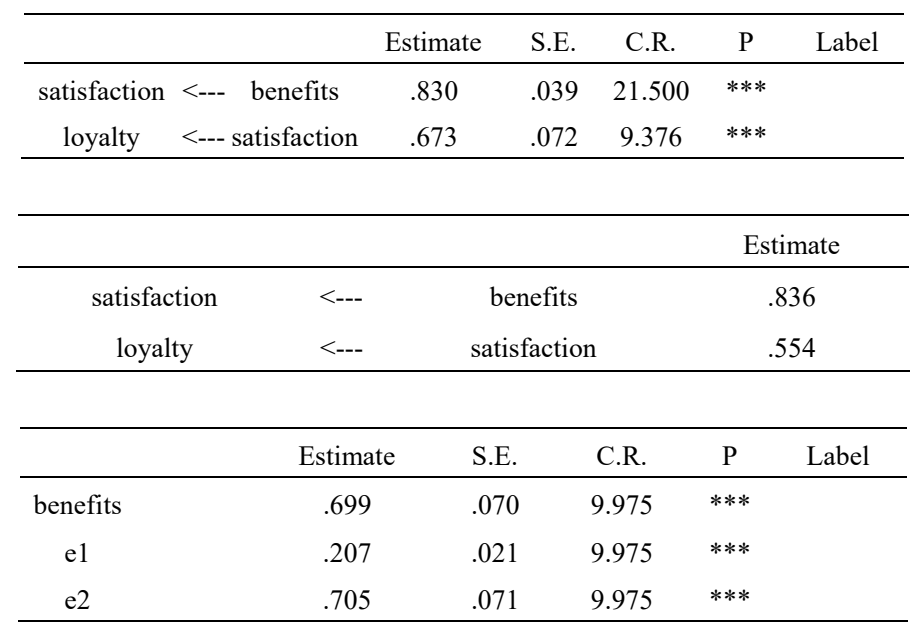

All of the measurements of the equations were statistically significant at a significance level of 0.05 , and the measures of reliability and variance extracted from the constructs were all significant.

Table 9. Regression Weights: (Group number 1 - Default model)

\begin{tabular}{lccccc}
\hline & Estimate & S.E. & C.R. & P & Label \\
\hline satisfaction <--- motivation & .208 & .030 & 7.029 & $* * *$ & \\
satisfaction <--- interaction & .284 & .031 & 9.275 & $* * *$ & \\
satisfaction <--- communication .382 & .032 & 12.113 & $* * *$ & \\
loyalty <--- satisfaction & .673 & .101 & 6.686 & $* * *$ & \\
\hline
\end{tabular}

Table 10. Standardized regression weights: (Group number 1 - Default model)

\begin{tabular}{llll}
\hline & & Estimate \\
\hline satisfaction & $<---$ & motivation & .320 \\
satisfaction & $<---$ & interaction & .423 \\
satisfaction & $<--$ & communication & .552 \\
loyalty $\quad<---$ & satisfaction & .428 \\
\hline
\end{tabular}

Table 11. Variances: (Group number 1 - Default model)

\begin{tabular}{lccccc}
\hline & Estimate & S.E. & C.R. & P & Label \\
\hline motivation & .834 & .084 & 9.975 & $* * *$ & \\
interaction & .778 & .078 & 9.975 & $* * *$ & \\
communication & .730 & .073 & 9.975 & $* * *$ & \\
$\mathrm{e} 1$ & .145 & .015 & 9.975 & $* * *$ & \\
$\mathrm{e} 2$ & .705 & .071 & 9.975 & $* * *$ & \\
\hline
\end{tabular}

Table 12. Squared Multiple Correlations: (Group number 1 - Default model)

\begin{tabular}{ll}
\hline & Estimate \\
\hline satisfaction & .586 \\
loyalty & .183 \\
\hline
\end{tabular}


Table 13. Matrices (Group number 1 - Default model)

Total Effects (Group number 1 - Default model)

\begin{tabular}{lllll}
\hline & communication & interaction & motivation & satisfaction \\
\hline satisfaction & .382 & .284 & .208 & .000 \\
loyalty & .257 & .191 & .140 & .673 \\
\hline
\end{tabular}

Standardized Total Effects (Group number 1 - Default model)

\begin{tabular}{lllll}
\hline & communication & interaction & motivation & satisfaction \\
\hline satisfaction & .552 & .423 & .320 & .000 \\
loyalty & .236 & .181 & .137 & .428 \\
\hline
\end{tabular}

Direct Effects (Group number 1 - Default model)

\begin{tabular}{lllll}
\hline & communication & interaction & motivation & satisfaction \\
\hline satisfaction & .382 & .284 & .208 & .000 \\
loyalty & .000 & .000 & .000 & .673 \\
\hline
\end{tabular}

Standardized Direct Effects (Group number 1 - Default model)

\begin{tabular}{lllll}
\hline & communication & interaction & motivation & satisfaction \\
\hline satisfaction & .552 & .423 & .320 & .000 \\
loyalty & .000 & .000 & .000 & .428 \\
\hline
\end{tabular}

Indirect Effects (Group number 1 - Default model)

\begin{tabular}{lllll}
\hline & communication & interaction & motivation & satisfaction \\
\hline satisfaction & .000 & .000 & .000 & .000 \\
loyalty & .257 & .191 & .140 & .000 \\
\hline
\end{tabular}

Standardized Indirect Effects (Group number 1 - Default model)

\begin{tabular}{lllll}
\hline & communication & interaction & motivation & satisfaction \\
\hline satisfaction & .000 & .000 & .000 & .000 \\
loyalty & .236 & .181 & .137 & .000 \\
\hline
\end{tabular}

Finally, to analyze the structural model fit, the significance of the estimated coefficients in the SEM was estimated. All of the estimated coefficients were significant. In the following figure, the estimated standardized regression coefficients are shown (all $t$ values exceed the reference values of 1.96 for a significant level of 0.05 ).

In summary,

- There is a mediating role of satisfaction in the impact of social media benefits on customer loyalty.

- There is a mediating role of satisfaction in the impact of communication on customer loyalty.

- There is a mediating role of satisfaction in the impact of interaction on customer loyalty.

- $\quad$ There is a mediating role of satisfaction in the impact of motivation on customer loyalty. 


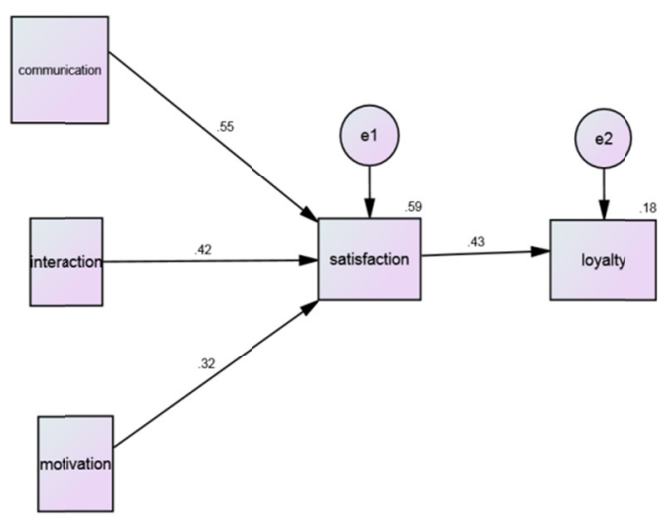

Figure 2. Amos model

\subsubsection{The Third Main Hypothesis}

Table 14. Model summary

\begin{tabular}{lllll}
\hline Model & R & R Square & Adjusted R Square & Std. Error of the Estimate \\
\hline 1 & $.889^{\mathrm{a}}$ & .790 & .786 & .38433
\end{tabular}

a. Predictors: (Constant), motivation, communication, interaction

Multiple Regressions is used to test the above hypothesis. Table (14) shows that R (0.889) is the impact of the independent variables on customer satisfaction. Also it is found that R Square (0.79), which is the explained variance, is actually the square of the multiple $\mathrm{R}(0.889) 2$. What the results mean is that (79\%) of the variance (R-Square) in the customer satisfaction variable was significantly explained by the independent variables.

Table 15. ANOVA ${ }^{\mathrm{b}}$

\begin{tabular}{lllllll}
\hline Model & & Sum of Squares & df & Mean Square & F & Sig. \\
\hline 1 & Regression & 108.724 & 3 & 36.241 & 245.355 & $.000^{\mathrm{a}}$ \\
& Residual & 28.951 & 196 & .148 & & \\
& Total & 137.676 & 199 & & & \\
\hline
\end{tabular}

a. Predictors: (Constant), motivation, communication, interaction.

b. Dependent Variable: satisfaction

The ANOVA table shows that the F value of (245.355) is significant at (0.05) level. Thus, there is statistically significant impact of social media benefits on customer satisfaction.

Table 16. Coefficients ${ }^{\mathrm{a}}$

\begin{tabular}{|c|c|c|c|c|c|c|}
\hline \multirow[b]{3}{*}{ Model } & & \multirow{2}{*}{\multicolumn{2}{|c|}{ Unstandardized Coefficients }} & \multirow{2}{*}{\multicolumn{2}{|c|}{$\begin{array}{l}\text { Standardized } \\
\text { Coefficients }\end{array}$}} & \multirow[b]{3}{*}{ Sig. } \\
\hline & & & & & & \\
\hline & & $\mathrm{B}$ & Std. Error & Beta & $\mathrm{t}$ & \\
\hline \multirow[t]{4}{*}{1} & (Constant) & .203 & .130 & & 1.562 & .120 \\
\hline & communication & .382 & .077 & .394 & 4.985 & .000 \\
\hline & interaction & .284 & .080 & .302 & 3.554 & .000 \\
\hline & motivation & .208 & .070 & .228 & 2.981 & .003 \\
\hline
\end{tabular}

a. Dependent Variable: satisfaction

Also according to the coefficient table it is found that $\mathrm{T}_{-}$value for the each variable is significant at $\mathrm{P}(0.05)$ levels. From the tables we conclude that: 
- There's a statistical significant impact of social media benefits collectively on customer satisfaction.

- There is a statistical significant impact of interaction on customer satisfaction.

- $\quad$ There is statistically significant impact of communication on customer satisfaction

- There is statistically significant impact of motivation on customer satisfaction.

4.4.4 Fourth Main Hypothesis

Table 17. Model summary

\begin{tabular}{lllll}
\hline Model & $\mathrm{R}$ & $\mathrm{R}$ Square & Adjusted R Square & Std. Error of the Estimate \\
\hline 1 & $.554 \mathrm{a}$ & .306 & .303 & .84400 \\
\hline
\end{tabular}

a. Predictors: (Constant), satisfaction

Linear Regression is used to test the above hypothesis. It is found that $\mathrm{R}(0.554)$ is the impact of satisfaction on customer' loyalty. Also it is found that R Square (0.306), which is the explained variance, is actually the square of the multiple $\mathrm{R}(0.554) 2$. What the results mean is that $(30.6 \%)$ of the variance (R-Square) in the customer loyalty variable has been significantly explained by satisfaction.

Table 18. ANOVAb

\begin{tabular}{lllllll}
\hline Model & & Sum of Squares & df & Mean Square & F & Sig. \\
\hline 1 & Regression & 62.308 & 1 & 62.308 & 87.470 & $.000 \mathrm{a}$ \\
& Residual & 141.043 & 198 & .712 & & \\
& Total & 203.351 & 199 & & & \\
\hline
\end{tabular}

a. Predictors: (Constant), satisfaction

b. Dependent Variable: loyalty

Table 19. Coefficientsa

\begin{tabular}{|c|c|c|c|c|c|c|}
\hline \multirow[b]{3}{*}{ Model } & & \multirow{2}{*}{\multicolumn{2}{|c|}{ Unstandardized Coefficients }} & \multicolumn{3}{|c|}{ Standardized } \\
\hline & & & & \multicolumn{3}{|c|}{ Coefficients } \\
\hline & & $\mathrm{B}$ & Std. Error & Beta & $\mathrm{t}$ & Sig. \\
\hline \multirow[t]{2}{*}{1} & (Constant) & .170 & .267 & & .635 & .526 \\
\hline & satisfaction & 673 & .072 & .554 & 9.353 & .000 \\
\hline
\end{tabular}

a. Dependent Variable: loyalty.

The ANOVA table shows that the F value of (87.47) is significant at (0.05) level. Thus, there is statistically significant impact of satisfaction on customer' loyalty.

As for marketing managers' sample Pearson correlation is used to test relationships between variables.

\section{Conclusions, Implications and Recommendations}

\subsection{The Main Findings That Are Concluded Through the Questionnaire Given To Customers}

The main goal of the present study is represented in aiming to identify whether there's any impact for social media benefits on customers' loyalty in Jordanian hotels. In general, the results showed that social media benefits have an impact on customers' loyalty in Jordanian hotels.

Second: The study's second objective is represented in aiming to identify whether there's any mediating impact for satisfaction on the relationship between social media benefits and customer loyalty in Jordanian hotel. It was concluded that satisfaction has a mediating impact on the relationship between social media benefits and customers' loyalty.

Third, the study's third objective is represented in aiming to investigate the impact of communication on customers' loyalty in Jordanian hotels. The study found that communication doesn't have any impact on customers' loyalty in Jordanian hotels

Fourth, the study's fourth objective is represented in aiming to investigate the impact of interaction on customers' 
loyalty in Jordanian hotels. It was concluded that there is an impact for interaction on customers' loyalty in Jordanian hotels

Fifth, the study's fourth objective is represented in aiming to investigate the impact of motivation on customers' loyalty in Jordanian hotels. It was concluded that motivation doesn't have any impact on customers' loyalty.

Sixth, the last objective is represented in seeking to identify which benefit of social media has the greatest impact on customers' loyalty in Jordanian hotels. It was concluded that interaction has the greatest impact on customers' loyalty.

\subsection{The Main Findings That Are Concluded Through the Questionnaire Given to the Marketing Managers}

The researcher retrieved 32 questionnaire forms from marketing managers of five-star hotels. It was concluded that there are significant positive impact for social media benefits on customers' satisfaction and thus, loyalty. Most of the sampled marketing managers rely on social media as being a vital part of their marketing strategy. They rely on it in promoting their services, increasing brand awareness, contacting new customers, retaining customers, building trust, and obtaining customers' feedback and recommendations about the concerned hotel.

\subsection{Theoretical Implications}

This present study aimed at analyzing the impact of social media benefits on customers' loyalty with exploring the impact of satisfaction as a mediating variable. It was concluded that there is a statistically significant positive impact of social media benefits and interaction on customers' loyalty. It was also concluded that there isn't any statistically significant impact for customers' communication and motivation on customers' loyalty.

Having statistically significant positive impact of social media benefits and interaction on customers' loyalty is in agreement with several studies. Those studies are: (Crofton and Parker, 2012; Zhang and Luo, 2016; Rehnen, et al. 2017; Ismail, 2017). All of those studies proved that social media benefit play a significant role in building loyalty. Marzouk, (2016) states that brand loyalty is the least positively affected factor of social media marketing.

Second, there isn't any statistically significant impact for customers' communication on customer loyalty. It is in agreement with (Olsen, 2015; ApenesSolem, 2016). However, the latter results aren't in agreement with the studies of (Leeflang et al. 2014; Zhang and Luo, 2016). That is because the latter researcher found a positive impact of communication on loyalty.

Third, there is a statistically significant impact for customers' interaction on customer loyalty. This result is in agreement with the studies of (Currás-Pérez et al. 2013; Sashi, 2012; Aluri el al, 2015; Ramanathan et al, 2017).

Fourth, there isn't any significant impact of motivation on customers' loyalty. This result is in agreement with the studies of (Marzouk, 2016). However, this result is not in agreement with the studies of (Duffett, 2015; Cawsey and Rowley, 2016; Crofton and paker, 2012; Rehnen, et al. 2017). That is because the latter researchers found a positive impact of motivation on loyalty.

Fifth, it was concluded that satisfaction has a mediating role on the way social media affects customer loyalty. This result is in agreement with the studies of (Clark et al. 2017; Lin and Lekhawipat, 2014; Srivastava and Kaul, 2014; Ghane et al. 2011).

Finally, there is a statistically significant impact for satisfaction on customers' loyalty. This result is in agreement with the studies of (Kuikka and Laukkanen, 2012; Lin and Lekhawipat, 2014; Greve, 2014; Dieck et al, 2017; Chang et al. 2014). The conclusion of the present study is presented in the table below:

Table 20. The Conclusion of the Present Study

\begin{tabular}{|c|c|c|}
\hline $\begin{array}{l}\text { The research was conducted in Jordanian } \\
\text { hotels }\end{array}$ & $\begin{array}{l}\text { (Mediating variable) } \\
\text { 2. Satisfaction }\end{array}$ & $\begin{array}{l}\text { (Dependent variable) } \\
\text { 3. Customers' loyalty }\end{array}$ \\
\hline (Independent variables) & Influential & Influential \\
\hline \multicolumn{3}{|l|}{ 1. Social media benefits } \\
\hline 1.1 Communication & Influential & Not Influential \\
\hline 1.2 Interaction & Influential & Influential \\
\hline 1.3 Motivation & Influential & Not Influential \\
\hline
\end{tabular}




\subsection{Managerial Implications}

The results of the present study shall participate in solving problems faced by hotels in the use of social media websites. Such results shall enable hotels to make their use of social media an efficient and effective use instead of using such websites for communicating with customers. Also, the results of the present study shall participate in achieving sustainable development for hotels, fulfilling their goals, and raising the quality of the services they provide.

\subsection{Recommendations}

The main goal of the present study is represented in seeking to identify the impact of social media on customer behavior and the impact of their satisfaction on the relationship between social media benefits and customer loyalty. It also aimed at identifying hotel marketing managers' opinions about their ability to effect on their customers' loyalty through using social media.

The previous studies involve a large number of variables related to social media benefits, such as: (brand awareness, trust, engagement, value, and etc...). However, the present study has shed a light on three variables; communication, interaction, and motivation in Jordanian hotels. It was proved that social media has an impact on customer loyalty. Such an impact can be attributed to the wide spread of social networking sites among people and the easiness of using them. Such an impact can be attributed to the efforts and time saved through using social media channels. It was concluded that interaction affects customer loyalty due to the easiness of handling customers' complaints and making suggestion through using social media.

Hence, it is necessary to conduct more studies in order to have a deeper understanding for interaction and its impact on loyalty. On the other hand, communication and motivation affect customers' satisfaction, but do not affect customer loyalty towards the hotel. Thus, future studies must provide managers with methods to improve the efficiency and effectiveness of communicating with customers and motivating them through social media. It was concluded that satisfaction affects customers' loyalty. Such satisfaction creates a sense of belonging to the hotel.

The present study shall help the marketing managers of Jordanian hotels in identifying and understanding the significance of social networking sites. It shall help in strengthening the hotel's interaction with customers to enhance customer loyalty.

In the light of the study's results, the researcher of the present study advises hotel marketing managers to have up-to-date information about the new advancements and developments related to social network websites. He also advises hotel managers to make use of the services provided through those websites, such as: publishing pictures, videos, and live videos. That is because such use shall directly affect customers' attitudes, and thoughts. In addition, the researcher also advises those managers to have up-to-date information about the popular marketing tools and be familiar with popular hash tags. The researcher recommends providing more attention to the electronic word of mouth marketing because it has a major impact on the purchasing decisions made by customers. The researcher advises marketing managers to pay more attention to customers' complaints and feedback. That is because such complaints shall enable hotels to improve the quality of the provided services. Furthermore, the researcher recommends providing customers with offers and services that are consistent with customers' needs and desires.

\section{References}

Abu-ELSamen, A. A., Akroush, M. N., Al-Khawaldeh, F. M., \& Al-Shibly, M. S. (2011). Towards an integrated model of customer service skills and customer loyalty: The mediating role of customer satisfaction. International Journal of Commerce and Management, 21(4), 349-380. https://doi.org/10.1108/10569211111189365

Alalwan, A. A., Rana, N. P., Algharabat, R., \& Tarhini, A. (2016, September). A Systematic Review of Extant Literature in Social Media in the Marketing Perspective. In Conference on e-Business, e-Services and e-Society (pp. 79-89). Springer International Publishing. https://doi.org/10.1007/978-3-319-45234-0_8

Aluri, A., Slevitch, L., \& Larzelere, R. (2015). The effectiveness of embedded social media on hotel websites and the importance of social interactions and return on engagement. International Journal of Contemporary Hospitality Management, 27(4), 670-689. https://doi.org/10.1108/IJCHM-09-2013-0415

ApenesSolem, B. A. (2016).Influences of customer participation and customer brand engagement on brand loyalty. Journal of Consumer Marketing, 33(5), 332-342. https://doi.org/10.1108/JCM-04-2015-1390

Bharwani, S., \& Mathews, D. (2016). Customer service innovations in the Indian hospitality industry. Worldwide Hospitality and Tourism Themes, 8(4), 416-431. https://doi.org/10.1108/WHATT-04-2016-0020 
Cawsey, T., \& Rowley, J. (2016). Social media brand building strategies in B2B companies. Marketing Intelligence \& Planning, 34(6), 754-776. https://doi.org/10.1108/MIP-04-2015-0079

Chang, S. C., Chou, P. Y., \& Wen-Chien, L. (2014).Evaluation of satisfaction and repurchase intention in online food group-buying, using Taiwan as an example. British Food Journal, 116(1), 44-61. https://doi.org/10.1108/BFJ-03-2012-0058

Clark, M., Black, H. G., \& Judson, K. (2017). Brand community integration and satisfaction with social media sites: a comparative study. Journal of Research in Interactive Marketing, 11(1), 39-55. https://doi.org/10.1108/JRIM-07-2015-0047

Crofton, S., \& Parker, R. (2012). Economic Impacts of Introducing Social Media as Marketing Tools in Atlantic Canadian Tourism Websites. In 2012 Economic Business and Historical Society Annual Conference, Las Vegas, Nevada.

Currás-Pérez, R., Ruiz-Mafé, C., \& Sanz-Blas, S. (2013). Social network loyalty: evaluating the role of attitude, perceived risk and satisfaction. Online Information Review, 37(1), 61-82. https://doi.org/10.1108/14684521311311630

Das, P., \& Mandal, S. (2016). Evaluating the influence of social media on brand sacralization: An empirical study among young online consumers. South Asian Journal of Global Business Research, 5(3), 424-446. https://doi.org/10.1108/SAJGBR-12-2015-0085

Duffett, R. G. (2015). Facebook advertising's influence on intention-to-purchase and purchase amongst Millennials. Internet Research, 25(4), 498-526. https://doi.org/10.1108/IntR-01-2014-0020

Farley, A. (2015), With Social Media, Focus on Your Fans' Engagement Level. ABA bank marketing and sales, Accepted for Publication.

Filo, K., Lock, D., \& Karg, A. (2015). Sport and social media research: A review. Sport management review, 18(2), 166-181. https://doi.org/10.1016/j.smr.2014.11.001

Gaikwad, J. M., \& Kate, P. H. (2016). E-Marketing: a modern approach of business at the door of consumer. Clear International Journal of Research in Commerce \& Management, 7(9).

George, D., \& Mallery, P. (2016). IBM SPSS statistics 23 step by step: A simple guide and reference. Routledge. https://doi.org/10.4324/9781315545899

Ghane, S., Fathian, M., \& Gholamian, M. R. (2011). Full relationship among e-satisfaction, e-trust, e-service quality, and e-loyalty: The case of Iran e-banking. Journal of Theoretical and Applied Information Technology, 33(1), 1-6.

Greve, G. (2014). The moderating effect of customer engagement on the brand image-brand loyalty relationship. Procedia-Social and Behavioral Sciences, 148, 203-210. https://doi.org/10.1016/j.sbspro.2014.07.035

Ismail, A. R. (2017). The influence of perceived social media marketing activities on brand loyalty: The mediation effect of brand and value consciousness. Asia Pacific Journal of Marketing and Logistics, 29(1), 129-144. https://doi.org/10.1108/APJML-10-2015-0154

Kaplan, A. M., \& Haenlein, M. (2010). Users of the world, unite. The challenges and opportunities of Social Media. Business horizons, 53(1), 59-68. https://doi.org/10.1016/j.bushor.2009.09.003

Kaura, V., Durga Prasad, C. S., \& Sharma, S. (2015).Service quality, service convenience, price and fairness, customer loyalty, and the mediating role of customer satisfaction. International Journal of Bank Marketing, 33(4), 404-422. https://doi.org/10.1108/IJBM-04-2014-0048

Kim, B., Kim, S., \& Heo, C. Y. (2016). Analysis of satisfiers and dissatisfiers in online hotel reviews on social media. International Journal of Contemporary Hospitality Management, 28(9), 1915-1936. https://doi.org/10.1108/IJCHM-04-2015-0177

Kuikka, A., \& Laukkanen, T. (2012). Brand loyalty and the role of hedonic value. Journal of Product \& Brand Management, 21(7), 529-537. https://doi.org/10.1108/10610421211276277

Laroche, M., Habibi, M. R., \& Richard, M. O. (2013). To be or not to be in social media: How brand loyalty is affected by social media. International Journal of Information Management, 33(1), 76-82. https://doi.org/10.1016/j.ijinfomgt.2012.07.003

Leeflang, P. S., Verhoef, P. C., Dahlström, P., \& Freundt, T. (2014). Challenges and solutions for marketing in a digital era. European Management Journal, 32(1), 1-12. https://doi.org/10.1016/j.emj.2013.12.001 
Lin, C., \& Lekhawipat, W. (2014). Factors affecting online repurchase intention. Industrial Management \& Data Systems, 114(4), 597-611. https://doi.org/10.1108/IMDS-10-2013-0432

Llodra-Riera, I., Martínez-Ruiz, M. P., Jiménez-Zarco, A. I., \&Izquierdo-Yusta, A. (2015). Assessing the influence of social media on tourists' motivations and image formation of a destination. International Journal of Quality and Service Sciences, 7(4), 458-482. https://doi.org/10.1108/IJQSS-03-2014-0022

Marzouk, W. G. (2016). Usage and Effectiveness of Social Media Marketing in Egypt: An Organization Perspective. Jordan Journal of Business Administration, 12(1), 209-238. https://doi.org/10.12816/0030062

Ogbuji, B., \& Papazafeiropoulou, A. (2016). Social Media Strategies for Companies: A Comprehensive Framework. In Conference on e-Business, e-Services and e-Society (pp. 3-14). Springer International Publishing. https://doi.org/10.1007/978-3-319-45234-0_1

Olsen, C. I. (2015). Brand Loyalty on social media-can images make you more loyal. published Doctoral Dissertation, Copenhagen Business School, Copenhagen, Denmark.

Parveen, F., Jaafar, N. I., \& Ainin, S. (2016). Social media's impact on organizational performance and entrepreneurial orientation in organizations. Management Decision, 54(9), 2208-2234. https://doi.org/10.1108/MD-08-2015-0336

Ramanathan, U., Subramanian, N., \& Parrott, G. (2017). Role of social media in retail network operations and marketing to enhance customer satisfaction. International Journal of Operations \& Production Management, 37(1), 105-123. https://doi.org/10.1108/IJOPM-03-2015-0153

Rehnen, L. M., Bartsch, S., Kull, M., \& Meyer, A. (2017). Exploring the impact of rewarded social media engagement in loyalty programs. Journal of Service Management, 28(2). https://doi.org/10.1108/JOSM-10-2015-0338

Sashi, C. M. (2012). Customer engagement, buyer-seller relationships, and social media. Management decision, 50(2), 253-272. https://doi.org/10.1108/00251741211203551

Sekaran, U., \& Bougie, R. (2016). Research methods for business: A skill building approach. John Wiley \& Sons.

Song, S., \& Yoo, M. (2016).The role of social media during the pre-purchasing stage. Journal of Hospitality and Tourism Technology, 7(1), 84-99. https://doi.org/10.1108/JHTT-11-2014-0067

Srivastava, M., \& Kaul, D. (2014). Social interaction, convenience and customer satisfaction: The mediating effect of customer experience. Journal of Retailing and Consumer Services, 21(6), 1028-1037. https://doi.org/10.1016/j.jretconser.2014.04.007

Tabrizi, S., \& Kabirnejat, M. (2015). Management, Strategies, Tools, and Practices in e-marketing. Journal of Knowledge Globalization, 8(2).

Teng, S., Khong, K. W., Chong, A. Y. L., \& Lin, B. (2017). Persuasive Electronic Word-of-Mouth Messages in Social Media. Journal of Computer Information Systems, 57(1), 76-88. https://doi.org/10.1080/08874417.2016.1181501

Tom Dieck, M. C., Jung, T. H., Kim, W. G., \& Moon, Y. (2017). Hotel guests' social media acceptance in luxury hotels. International Journal of Contemporary Hospitality Management, 29(1), 530-550. https://doi.org/10.1108/IJCHM-10-2015-0552

Tsimonis, G., \& Dimitriadis, S. (2014). Brand strategies in social media. Marketing Intelligence \& Planning, 32(3), 328-344. https://doi.org/10.1108/MIP-04-2013-0056

Valos, M., Polonsky, M. J., Mavondo, F., \& Lipscomb, J. (2015). Senior marketers' insights into the challenges of social media implementation in large organizations: assessing generic and electronic orientation models as potential solutions. Journal of Marketing Management, 31(7-8), 713-746. https://doi.org/10.1080/0267257X.2014.977931

White, C. (2015). The impact of motivation on customer satisfaction formation: a self-determination perspective. European Journal of Marketing, 49(11/12), 1923-1940. https://doi.org/10.1108/EJM-08-2014-0501

Yuksel, M., \& Labrecque, L. I. (2016). "Digital buddies": parasocial interactions in social media. Journal of Research in Interactive Marketing, 10(4), 305-320. https://doi.org/10.1108/JRIM-03-2016-0023

Zhang, M., \& Luo, N. (2016). Understanding relationship benefits from harmonious brand community on social media. Internet Research, 26(4), 809-826. https://doi.org/10.1108/IntR-05-2015-0149 
Zizka, L. (2017). The (mis) use of social media to communicate CSR in hospitality: increasing stakeholders' (dis) engagement through social media. Journal of Hospitality and Tourism Technology, 8(1). https://doi.org/10.1108/JHTT-07-2016-0037

\section{Copyrights}

Copyright for this article is retained by the author(s), with first publication rights granted to the journal.

This is an open-access article distributed under the terms and conditions of the Creative Commons Attribution license (http://creativecommons.org/licenses/by/4.0/). 